\title{
ANALYSIS OF THE IMPACT OF THE PROPORTION OF INDEPENDENT COMMISSIONERS, LEVERAGE, AND SIZE ON THE ACCOUNTING CONSERVATISM OF STATE-OWNED ENTERPRISES (BUMN)
}

\author{
Sri Wahjuni Latifah ${ }^{1)}$, Saskiya Sasa Difananda ${ }^{2)}$ \\ Faculty of Economics and Business University of Muhammadiyah Malang ${ }^{1,2)}$ \\ sriwahjuni@umm.ac.id ${ }^{l}$,saskiyasasa12@gmail.com²
}

\begin{abstract}
This study intends to analyze the Impact of the Proportion of Independent Commissioners, Leverage, and Size on the Accounting Conservatism in State-Owned Enterprises (BUMN) listed on the Indonesia Stock Exchange (IDX) for the 2017-2019 period. Based on these objectives, there are important questions in this study: whether the variables of the Proportion of Independent Commissioners, Leverage, and size as independent variables impact accounting conservatism, which is the dependent variable. To answer this question, the researcher used the multiple linear regression analysis methods using the Stata15 application. Determination of the sample in this study using purposive sampling method based on specific criteria and the sample obtained is 51 company data. There are several implications in this study, namely theoretical implications and practical implications. Theoretically, this research can be a reference for further researchers in analyzing the effect of accounting conservatism. While practically, it can have implications for company management, especially in decision making, for investors in terms of consideration when making investments and creditors related to the company's credit activities. The results showed that the leverage variable impacted accounting conservatism, while the proportion of independent commissioners and size had no impact on accounting conservatism.
\end{abstract}

Keywords: Accounting Conservatism; Leverage; The Proportion of Independent Commissioners; Size

*Corresponding author :

Email: sriwahjuni@umm.ac.id

DOI: https://doi.org/10.33369/j.akuntansi.11.3.259-270

\section{INTRODUCTION}

Financial statements are a tool to obtain corporate financial information used by internal or external parties and used in decision making. Besides, financial statements can also assess the company's ability to meet liabilities, capital structure, use of assets, income, expenses, and stock book value (Savitri, 2016). Based on this, the company's management is given flexibility in choosing its accounting methods, one of which is to apply the principle of accounting conservatism (Kusamadewi, 2018).

The need to apply the principle of conservatism due to accounting using accrual basis informing and presenting financial statements (Savitri, 2016). However, accounting conservatism is still a debate, and some are pros and cons to its application. Despite these differences of opinion, the principle of accounting conservatism is still used. This is to offset the excessive optimism of managers by applying pessimism because of the tendency of managers to overestimate profits in financial statements. Some factors that are thought to influence companies in applying the principle of accounting conservatism are the proportion of independent commissioners, leverage, and the company's size.

The proportion of independent commissioners is the number of independent commissioners of all commissioners in the company. A high proportion of commissioners tend to direct management actions to apply the principle of accounting conservatism. Results of the Rajagukguk \& Rohman (2020), Pratanda \& Kusmuriyanto (2014), and Sonia Fitriani (2013) show that the proportion of independent commissioners affects accounting conservatism, while 

AND SIZE ON THE ACCOUNTING CONSERVATISM OF STATE-OWNED ENTERPRISES (BUMN)

Febriani et al. (2020) and Purwasih (2020) obtained the result that the proportion of independent commissioners does not affect accounting conservatism.

Leverage is a financial ratio used to determine the number of funding sources (debt) to corporate equity. Highly indebted companies give creditors have the right to know and supervise the company's operations (Susanto \& Ramadhani, 2016). This means that the more debt the company has, the tighter the creditors will monitor the company. Thus, higher leverage will affect contractual demand for conservative accounting (Putu et al., 2018). Results of the study Jao \& Ho (2019), Yuliarti \& Yanto (2017), Saputra (2016), and Pratanda \& Kusmuriyanto (2014) indicates that leverage has a Positive Impact on accounting conservatism. While Solichah \& Fachrurrozie (2019) and Kusamadewi (2018) the study results that leverage negatively affects accounting conservatism.

Another factor is the size of the company. Based on its size, the company is divided into small and large companies, where large companies have more complex management systems and high profits. Large companies will be charged high political costs, so the company uses conservative accounting to reduce the political costs (Wulandini \& Zulaikha, 2012). Results of the study Purwasih (2020), Solichah \& Fachrurrozie (2019), and Kusamadewi (2018) indicate that the size of the company positively affects accounting conservatism. At the same time, Yuliarti \& Yanto (2017) obtained the research results that the company's size negatively affects accounting conservatism.

This research is a replication of the research Rajagukguk \& Rohman (2020), Febriani et al. (2020), Purwasih (2020), Solichah \& Fachrurrozie (2019), Jao \& Ho (2019), Kusamadewi (2018), Yuliarti \& Yanto (2017), Saputra (2016), Pratanda \& Kusmuriyanto (2014), and Sonia Fitriani (2013). The renewal of this research is located in the object of research conducted at state-owned enterprises (SOEs) listed on the Indonesia Stock Exchange in 2017-2019. The selection of State-Owned Enterprises as the object of research because of the case related to the application of accounting conservatism has occurred in one of the State-Owned Enterprises, namely PT. Garuda Indonesia (Persero) Tbk in 2018. Financial statements of PT. Garuda Indonesia in 2018 recorded one of the transactions that have been recognized as revenue. The case at Garuda Indonesia shows the management's lack of prudence in presenting financial statements resulting in an overstatement of profit in 2018 (El-Haq et al., 2019).

Based on inconsistencies in the results of the study on the influence of the proportion of independent board of commissioners, leverage, and size of the company on accounting conservatism, as well as cases related to the lack of prudence of the company's management in financial reporting on one of the State-Owned Enterprises.

The purpose of this study is to test the influence of the proportion of independent commissioners, leverage and size of the company on accounting conservatism in State-Owned Enterprises registered in IDX in 2017-2019. The result of this study is helpful in adding references to research on Accounting Conservatism which is influenced by the Proportion of Independent Commissioners, Leverage, and Size in State-Owned Enterprises (BUMN). In addition, the results of this study can be considered by management for the application of Accounting Conservatism in presenting financial reports so as to produce quality reports and assist companies in making decisions. 


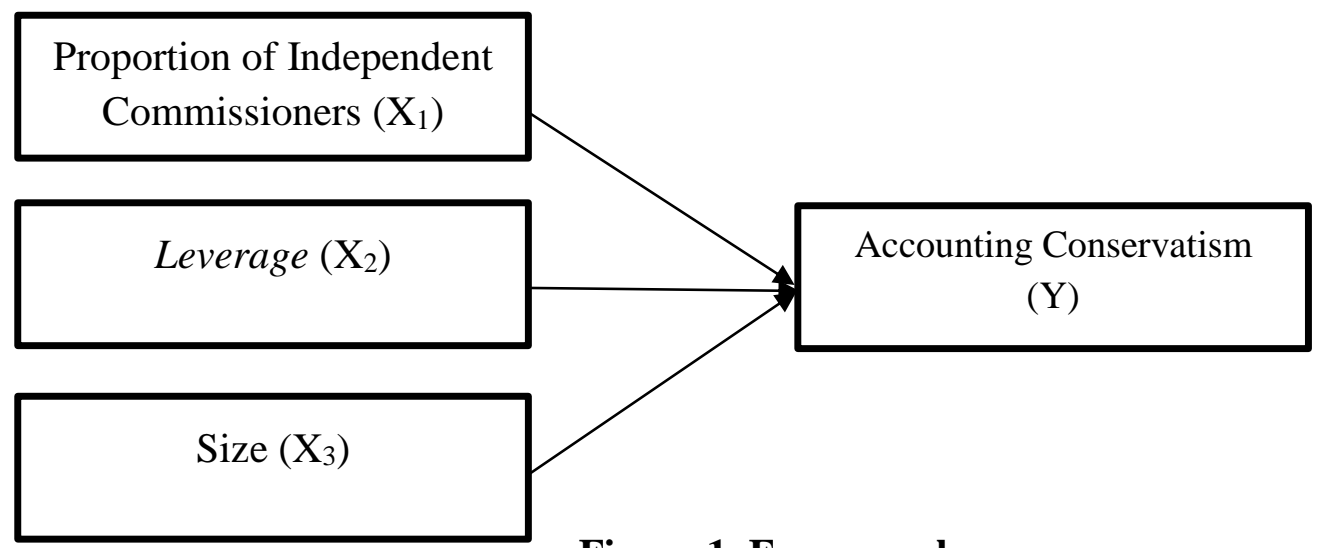

Figure 1. Framework

The existence of an independent commissioner in a company is very important related to monitoring the performance of management. A high proportion of independent commissioners in a company can disclose information more widely and can reduce agency costs (Rajagukguk \& Rohman, 2020). So, the greater the proportion of independent commissioners in a company, the higher the level of conservatism desired because of the requirements for higher quality financial information (Pratanda \& Kusmuriyanto, 2014). This is in accordance with research conducted by Rajagukguk \& Rohman (2020), Pratanda \& Kusmuriyanto (2014), and Sonia Fitriani (2013), that the Proportion of Independent Commissioners has an effect on Accounting Conservatism.

$\mathrm{H}_{1}$ : The Proportion of Independent Commissioners has a positive impact on Accounting Conservatism.

Companies that have high debt will choose the application of Accounting Conservatism (Sugiarto \& Nurhayati, 2017). This is also evident in research conducted by Jao \& Ho (2019), Varadina \& Diatmika (2018), Yuliarti \& Yanto (2017), R. E. Saputra (2016), and Dewi \& Suryanawa (2014) that leverage has a positive effect on Accounting Conservatism.

$\mathrm{H}_{2}$ : Leverage has a positive impact on Accounting Conservatism.

Large companies will incur high political costs. So to reduce these political costs, the company applies the concept of Accounting Conservatism. This has also been proven by Solichah \& Fachrurrozie (2019), Kusamadewi (2018), and Aristiyani \& Wirawati (2013) that firm size has a positive effect on Accounting Conservatism.

$\mathrm{H}_{3}$ : Size has a positive impact on Accounting Conservatism.

\section{RESEARCH METHODS}

The type of research is associative. The population of this research is state-owned enterprises (BUMN) registered in IDX in 2017-2019. Determination of samples using a purposive sampling method. The criteria for determining samples in this study are as follows:

1. State-Owned Enterprises registered in IDX in 2017-2019.

2. State-owned enterprises that have published annual reports for the period 2017-2019.

3. The company's Annual Report has included the completeness of data related to the needs of research variables.

4. Companies with extreme data are carried out outliers. 
The dependent variable in this study was accounting conservatism. Variable measurement refers to research Hayn \& Givoly (2000) which is also used by Andreas et al. (2017). The formula used is as follows:

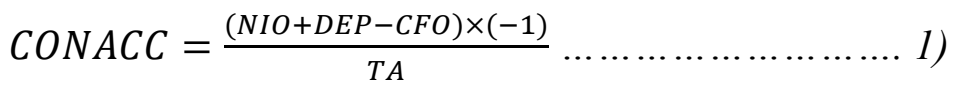

An independent variable is a variable that affects a bound variable, either positively or negatively (Sekaran \& Bougie, 2017). Here are the independent variables and their measurements:

1. The Proportion of Independent Commissioners $\left(\mathrm{X}_{1}\right)$

The proportion of independent commissioners is the number of independent commissioners and is measured by the percentage of the number of independent commissioners divided by the total number of commissioners.

Formula used:

$$
\left.P D K I=\frac{\text { Total of Independent Commissioners }}{\text { Total members of the board of commissioners }} \ldots \ldots \ldots \ldots \ldots 2\right)
$$

\section{Leverage $\left(\mathrm{X}_{2}\right)$}

Leverage is the ratio of total debt to total company assets.

Formula used:

$$
\text { DER }=\frac{\text { Total Liabilities }}{\text { Total Equity }} \times 100 \%
$$

\section{Size $\left(X_{3}\right)$}

Company size is a measure of the wealth owned by the company and the determination of the size of the company.

Formula Used:

Firm Size $=$ Ln Total Asset

The type of data used in this study is secondary data accessed through the IDX official website, namely www.idx.co.id. Data acquisition techniques are documentation. Besides, data analysis techniques are multiple regression analysis methods using the Stata15 application. The stages in analyzing the data are as follows:

1. Data Tabulation

Data tabulation is an activity to collect secondary data for research needs. Secondary data such as financial reports and annual reports of State-Owned Enterprises (BUMN) during the 2017-2019 period.

2. Descriptive Statistical Analysis

Descriptive statistics in this study described through the average value (mean), standard deviation, maximum, and minimum.

3. Classic Assumption Test
a. Normality Test
b. Multicollinearity Test
c. Heteroskedastisitas Test
d. Autocorrelation Test

4. Hypothesis Test
a. Coefesien Determination Test $\left(\mathrm{R}^{2}\right)$
b. Partial Test (t)
c. Simultaneous Test (F) 
The equation of multiple regression models is as follows:

$$
\begin{aligned}
& \left.Y=\alpha+b_{1} X_{1}+b_{2} X_{2}+b_{3} X_{3}+e \ldots \ldots \ldots . .5\right) \\
& \text { Description: } \\
& \mathrm{Y}=\text { Accounting Conservatism } \\
& \mathrm{a} \quad=\text { Konstanta } \\
& \mathrm{b}=\text { Regression Coefesien } \\
& \mathrm{X} 1=\text { The Proportion of Independent Commissioners } \\
& \mathrm{X} 2=\text { Leverage } \\
& \mathrm{X} 3=\text { Size } \\
& \mathrm{e} \quad=\text { Error }
\end{aligned}
$$

\section{RESULTS AND DISCUSSION}

\section{Overview of Research Data}

State-Owned Enterprises (BUMN) are business entities in which the state is the owner of all or most of the company's capital derived from the state's separated wealth (Indonesia, 2003).

Table 1. Stages of Research Sample Selection

\begin{tabular}{clc}
\hline No & \multicolumn{1}{c}{ Criteria } & Total \\
\hline 1 & $\begin{array}{l}\text { State-Owned Enterprises (BUMN) listed on the Indonesia Stock } \\
\text { Exchange (IDX) in 2017-2019. }\end{array}$ & 25 \\
\hline 2 & $\begin{array}{l}\text { State-Owned Enterprises that do not publish financial statements for the } \\
\text { period 2017-2019. }\end{array}$ & 0 \\
\hline 3 & Companies that do not have complete data related to research variables. & 0 \\
\hline 4 & Companies are outliers because of extreme data. & 8 \\
\hline & Total Samples & 17 \\
\hline
\end{tabular}

Source: Data processed, 2021

Based on the data above, it is known that 75 companies are the population in this study. After being selected based on specific criteria, a sample of 51 company data was obtained. In the first and second criteria, all State-Owned Enterprises have met the criteria. In the third criterion, based on the company categorized as an outlier in this study, eight companies that were declared outliers had to be excluded from the research object. Companies declared outliers such as PT Bank Rakyat Indonesia (Persero) Tbk, PT Bank Tabungan Negara (Persero) Tbk, PT Elnusa Tbk, PT Garuda Indonesia (Persero) Tbk, PT Kimia Farma (Persero) Tbk, PT Krakatau Steel (Persero) Tbk, PT Timah Tbk, and PT Telekomunikasi Indonesia Tbk.

\section{The Result of Descriptive Statistical Test}

Table 2. The Result of Descriptive Statistical Test

\begin{tabular}{lccccc}
\hline & N & Minimum & Maximum & Mean & Std. Deviation \\
\hline PDKI & 51 & 0,000 & 0,80 & 0,3593 & 0,16172 \\
\hline LEV & 51 & 0,417 & 9,78 & 2,6651 & 2,27380 \\
\hline UP & 51 & 22,721 & 36,50 & 30,8888 & 2,67690 \\
\hline KONV_AKT & 51 & $-0,350$ & 0,039 & $-0,1203$ & 0,10914 \\
\hline Valid N (listwise) & 51 & & & \\
\hline Source: Data Processing Results by Stata15, 2021
\end{tabular}


Based on the results, the amount of data $(\mathrm{N})$ in this study is 51 samples of companies derived from the financial report data of State-Owned Enterprises listed on IDX in 2017-2019. The results of the analysis can be seen in the following details:

1. The Proportion of Independent Commissioners

Based on the descriptive statistical tests obtained the lowest value (minimum) of The proportion of independent commissioners is 0.000 , this value is owned by the company PT Waskita Beton Precast Tbk in 2017, 2018, and 2019. The highest value (maximum) is 0.80, this value is owned by PT Bank Pembangunan Daerah Jawa Barat dan Banten Tbk. Also, the average value (mean) obtained is 0.3593 with a standard deviation value (Std. Deviation) of 0.16172 . The analysis results showed that the mean is greater than the standard deviation value, which means homogeneous data where the average value of the proportion of independent commissioners has a low deviation rate.

2. Leverage

Based on the descriptive statistical tests obtained the lowest value (minimum) Leverage is 0.417, PT Bukit Asam Tbk owns this value in 2019, meaning the company has a low level of debt and risks borne by the company is low because of the leverage obtained 42.7\%. While the highest value is 6.08 owned by PT Bank Pembangunan Daerah Jawa Barat dan Banten Tbk, which means the company has a high level of debt, and the risk borne by the company is also high. Also, the average value (mean) obtained is 2.6651 , which means that State-Owned Enterprises generally have higher debt than their equity because the ratio is 2.6651 compared to 1.00. While the standard deviation value (Std. Deviation) is 2.27380.

3. Size

Based on descriptive statistical tests obtained the lowest value (minimum) size value is 22,721 from the company PT Gas Negara Tbk in 2019. While the highest value (maximum) is 36.50 obtained from the company PT Bank Negara Indonesia (Persero) Tbk in 2017. Also, the mean obtained is 30.8888 with a standard deviation of 2.67690. The difference between PT Gas Negara Tbk in 2019 and PT Bank Negara Indonesia in 2017 has a big difference. Based on this, it is known that the size of State-Owned Enterprises is small and some are large.

4. Accounting Conservatism

Based on the descriptive statistical tests obtained the lowest accounting conservatism value (minimum) is -0.350 , the value is owned by PT Semen Indonesia (Persero) Tbk, which means that PT Semen Indonesia (Persero) Tbk implements the lowest principle of accounting conservatism. While the highest value (maximum) is 0.039 owned by the company PT Jasa Marga (Persero) Tbk in 2017 which means that the company applies the highest principle of accounting conservatism compared to other State-Owned Enterprises. Also, obtained an average value (mean) of -0.1203 with a standard deviation value (Std. Deviation) of 0.10914 this means that the data is heterogeneous because the distribution of data varies so that the average accounting conservatism has a high level of deviation.

\section{The Results of Classic Assumption Test \\ 1. Normality Test}

Based on the table, it can be known the reciprocal probability value $>0.05$ which is 0.2835 . This suggests that the data used in this study is normal. As for the skewness and kurtosis test values are said to be distributed normally if the value obtained is between -2 and 2. Based on the results of the analysis in the table above, it can be known that the residual skewness value of 0.1868 and kurtosis 0.4209 which means it is still between -2 and 2, it can be said that the data is normally distributed. 
Table 3. The Result of Normality Test

\begin{tabular}{cccccc}
\hline Variable & Obs & $\operatorname{Pr}($ Skewness $)$ & $\operatorname{Pr}($ Kurtosis) & adj chi2(2) & Prob>chi2 \\
\hline res & 51 & 0,1868 & 0,4209 & 2,52 & 0,2835 \\
\hline
\end{tabular}

Source: Data Processing Results by Stata15, 2021

\section{Multicollinearity Test}

Table 4. The Result of Multicollinearity Test

\begin{tabular}{lccl}
\hline \multirow{2}{*}{ Variable } & \multicolumn{2}{c}{ Collinearity Statistics } & \\
\cline { 2 - 3 } & Tolerance & VIF & \\
\hline PDKI & 0,529 & 1,89 & Conclusion \\
\hline LEV & 0,640 & 1,56 & No Multicollinearity Occurs \\
\hline UP & 0,738 & 1,36 & No Multicollinearity Occurs \\
\hline
\end{tabular}

Source: Data Processing Results by Stata15, 2021

Based on the table above, known tolerance values for the proportion of independent commissioners, leverage, and company size of $0.529,0.640$, and 0.738 are $>0.10$ and VIF respectively $1.89,1.56$, and $1.36<10$, meaning that there is no multicollinearity between independent variables.

\section{Heteroskedastisitas Test}

Table 5. The Result of Heterokedastisitas Test

\begin{tabular}{lll}
\hline & Prob. Chi-Square & Conclusion \\
\hline Constant & 0,2990 & Does not occur heteroskedasticity \\
\hline Source: Data Processing Results by Stata 15,2021
\end{tabular}

Source: Data Processing Results by Stata15, 2021

Based on the results of the heteroskedasticity test in table above, it is known that the significance value of $0.2990>0.05$, which means that there is no heteroskedasticity and a good regression model.

\section{Autocorrelation Test}

Table 6. The Result of Autocorrelation Test

\begin{tabular}{ccc}
\hline Model & Durbin-Watson & Conclusion \\
\hline 1 & 0,1078 & No positive autocorrelation \\
\hline Source: Data Processing & Results by Stata15, 2021
\end{tabular}

Based on table 6 above, the durbin-watson value obtained by 0.1078 , a comparison using significance value 5\%, sample number 51 (n) and a number of independent variables $3(\mathrm{k}=3)$, then in the table Durbin-Watson will get dU value of 1.6754 and $\mathrm{dL}$ of 1.4273 . From these results, it is known that the value of Durbin Watson is below the value of $\mathrm{dL}$ or $0<$ $0.1078<1.4273$. Then it can be said that there is no positive autocorrelation.

\section{Hypothesis Test}

\section{Coefesien Determination Test $\left(\mathbf{R}^{2}\right)$}

Based on the coefesien determination test results, the adjusted R-square value is 0.3185 or $31.85 \%$. This shows that $31.85 \%$ of variations in accounting conservatism can be explained by variable proportions of independent commissioners, leverage, and company size while the remaining $68.15 \%$ is explained by other variables outside the model studied. 
ANALYSIS THE IMPACT OF THE PROPORTION OF INDEPENDENT COMMISSIONERS, LEVERAGE, AND SIZE ON THE ACCOUNTING CONSERVATISM OF STATE-OWNED ENTERPRISES (BUMN)

Sri Wahjuni Latifah and Saskiya Sasa Difananda

Table 7. The Result of $\mathbf{R}^{2}$ Test

\begin{tabular}{lll}
\hline & R-Squared & Adj R-Squared \\
\hline Cource: Data Processing Results by Stata15, 2021 & 0,3185 \\
\hline
\end{tabular}

2. Simultaneous Test (F)

Table 8. The Result of $F$ Test

\begin{tabular}{lll}
\hline & Prob $>\mathrm{F}$ & Conclusion \\
\hline Constant & 0,0001 & $\begin{array}{l}\text { Model built between each dependent } \\
\text { variable against the dependent variable } \\
\text { has been good }\end{array}$ \\
\hline
\end{tabular}

Source: Data Processing Results by Stata15, 2021

Based on table above the test value $F$ is 0.0001 which is smaller than 0.05 , so it can be concluded that independent variables that are the proportion of independent board of commissioners, leverage, and size of the company simultaneously or jointly affect accounting conservatism. Thus, it can be concluded that the model built between each dependent variable against the dependent variable has been good.

\section{Partial Test (t)}

Table 9. The Result of Partial Significance Test (t)

\begin{tabular}{lcccccc}
\hline \multicolumn{1}{c}{ Var } & Coef. & Std. Err. & $\mathrm{t}$ & $\mathrm{P}>|\mathrm{t}|$ & \multicolumn{2}{c}{ [95\% Conf. Interval] } \\
\hline PDKI & 0,029 & 0,098 & 0,30 & 0,768 & $-0,1689$ & 0,2274 \\
\hline LEV & 0,019 & 0,008 & 2,58 & 0,013 & 0,0043 & 0,0353 \\
\hline UP & 0,010 & 0,006 & 1,76 & 0,085 & $-0,0014$ & 0,0209 \\
\hline cons & $-0,485$ & 0.165 & $-2,95$ & 0,005 & $-0,8157$ & $-0,1537$ \\
\hline
\end{tabular}

Source: Data Processing Results by Stata15, 2021

The results of the t-test on each independent variable are as follows:

a. Proportion of Independent Board of Commissioners

The variable significance value of the proportion of independent commissioners is 0.768 , which means that sig SKM $\left(\mathrm{X}_{1}\right)>0.05$. Thus it can be concluded that the variable proportion of the independent board of commissioners has no Impact on accounting conservatism or hypothesized $1\left(\mathrm{H}_{1}\right)$ is rejected.

b. Leverage

The value of leverage significance is 0.013 , meaning that sig Lev $\left(\mathrm{X}_{2}\right)<0.05$. Then it can be concluded that leverage variables affect accounting conservatism or hypothesis $2\left(\mathrm{H}_{2}\right)$ accepted.

c. Company Size

The value of the significance of the company size of 0.085 , meaning $\operatorname{sig} \mathrm{UP}\left(\mathrm{X}_{3}\right)>0.05$. It can then be concluded that the company's variable size has no Impact on accounting conservatism or the $3\left(\mathrm{H}_{3}\right)$ hypothesis is rejected.

In addition to the partial test results (statistical test $\mathrm{t}$ ), the analysis results in table 9 can also be seen for analysis of multiple linear regressions in the coef column. Based on the analysis obtained, the double linear regression equation is as follows:

$\left.Y=\alpha+b_{1} X_{1}+b_{2} X_{2}+b_{3} X_{3}+e \ldots \ldots \ldots \ldots \ldots \ldots \ldots \ldots 6\right)$

$\mathrm{Y}=-0,485+0,029 \mathrm{PDKI}+0,019 \mathrm{LEV}+0,010 \mathrm{UP}+e \ldots \ldots . .7)$ 
The equation can be described as follows:

a. A variable proportion of independent commissioners who have a regression coefesien value of 0.029 means that each quantitative increase in the proportion of independent commissioners by 1 unit assuming other independent variables remain, conservatism will increase by 0.029 units.

b. A Leverage variable that has a regression coefesien value of 0.019 means that every quantitative increase in leverage of 1 unit assuming other independent variables remain, conservatism will increase by 0.019 units.

c. Variable size of companies that have a regression coefesien value of 0.010 means that each quantitative increase in the size of the company by 1 unit assuming other independent variables remain, conservatism will increase by 0.010 units.

\section{Discussion}

Table 10. The Result of Hypothesis Test

\begin{tabular}{clc}
\hline Code & \multicolumn{1}{c}{ Hypothesis } & Results \\
\hline $\mathrm{H}_{1}$ & $\begin{array}{l}\text { The Proportion of Independent Commissioners has a positive } \\
\text { impact on Accounting Conservatism. }\end{array}$ & Rejected \\
\hline $\mathrm{H}_{2}$ & Leverage has a Positive Impact on Accounting Conservatism & Accepted \\
\hline $\mathrm{H}_{3}$ & Size has a positive impact on Accounting Conservatism. & Rejected \\
\hline
\end{tabular}

\section{The Impact of the Proportion of Independent Commissioners on Accounting Conservatism}

Based on the results of the first hypothesis $(\mathrm{H} 1)$, the proportion of independent commissioners does not affect accounting conservatism. This can be seen from the significant value in the t-test or partial test which is worth 0.768 . Based on the test, it is known that $0.768>0.05$, which means hypothesis $1\left(\mathrm{H}_{1}\right)$ is rejected. This is in line with the research conducted by Febriani et al. (2020) and Purwasih (2020) which indicates that variable proportions of the independent board of commissioners do not affect accounting conservatism.

According to Febriani et al. (2020), the proportion of commissioners is considered to have an abnormal level of control, besides that the existence of independent commissioners only meets formal policies. According to Purwasih (2020), the absence of independent commissioner influence accounting conservatism because independent commissioners are parties from outside the company that causes information obtained by independent commissioners is also relatively limited. Therefore, the role of independent commissioners in improving the company's performance is less Impactive. This indicates that the level of supervision and application of conservatism by independent commissioners is not Impactive.

According to agency theory, one of the actions taken by the principal to achieve its functions and objectives is to report profits with the aim of maximizing personal or company interests with accounting methods using the principles of Accounting Conservatism. In BUMN, it turns out that the principals represented by the Board of Independent Commissioners does not focus on profit reporting but is more concerned with the public interest or the interests of the state. However, the results of this study are not in line with the results of research conducted by Rajagukguk \& Rohman (2020), Pratanda \& Kusmuriyanto (2014), and Sonia Fitriani (2013) which gets the result that the proportion of independent commissioners affects accounting conservatism. 
ANALYSIS THE IMPACT OF THE PROPORTION OF INDEPENDENT COMMISSIONERS, LEVERAGE, AND SIZE ON THE ACCOUNTING CONSERVATISM OF STATE-OWNED ENTERPRISES (BUMN)

Sri Wahjuni Latifah and Saskiya Sasa Difananda

\section{The Impact of the Leverage on Accounting Conservatism}

Based on the results of the second hypothesis, leverage affects accounting conservatism. This can be seen from the significant value in the t-test of 0.013 . Based on the test, it is known that $0.013<0.05$ which means hypothesis $2\left(\mathrm{H}_{2}\right)$ is accepted. This is in line with research conducted by Jao \& Ho (2019), Yuliarti \& Yanto (2017), Saputra (2016), and Pratanda \& Kusmuriyanto (2014) that leverage positively affects accounting conservatism.

According to Jao \& Ho (2019), the high level of corporate debt makes creditors have the right to supervise the operation of the company and creditors can also demand the application of the principle of conservatism in financial reporting because creditors are interested in the security of refunds lent. Besides, according to Yuliarti \& Yanto (2017), the higher leverage, the greater the company's financial obligations.

Based on the results of descriptive statistical analysis, it is known that the average value (mean) leverage in State-Owned Enterprises during the period 2017-2019 is 2.439342, which means that State-Owned Enterprises, in general, have higher debt than their equity because the ratio is 2.6651 compared to 1.00 . Due to high debt, creditors tend to encourage companies to apply the principle of conservatism in financial reporting for the security of the funds they lend. This is in accordance with agency theory that companies that have large amounts of debt will take actions of conservatism to maintain the trust of lenders. However, this is not in line with the research conducted by Solichah \& Fachrurrozie (2019) and Kusamadewi (2018) leverage negatively affects accounting conservatism.

\section{The Impact of the Size on Accounting Conservatism}

Based on the results of the third hypothesis, the size of the company does not affect accounting conservatism. This can be seen from the significant value in the t-test of 0.085 . Based on the test, it is known that $0.085>0.05$ which means hypothesis $3\left(\mathrm{H}_{3}\right)$ is not accepted or rejected. This is in line with the research conducted by Yuliarti \& Yanto (2017) that the size of the company does not affect accounting conservatism.

According to Yuliarti \& Yanto (2017), company size has no Impact on accounting conservatism, which means the size of the company does not guarantee the company applies the principle. The larger the size of the company is not accompanied by the increase or decrease in the value of conservatism. Besides, according to Tista \& Suryanawa (2017), negative relationships are caused by large companies having complex activities so institutions tend to choose a more aggressive and optimistic strategy in the face of uncertainty and end up at a high-profit value. In contrast to small companies that avoid political costs because of the need for funds to grow their businesses.

Based on the phenomenon that occurred in the company PT Garuda Indonesia Tbk in 2018 that does not apply the principle of accounting conservatism, this shows that the large size of the company does not affect the Institutional company to apply the principle of conservatism. The application of accounting conservatism in state-owned enterprises is contrary to positive accounting theory especially for the hypothesis of political costs where large companies are more sensitive to political costs so tend to apply the principle of accounting conservatism.

In accordance with positive accounting theory, that political costs occur because of the interests between the company and government. The larger the size of the company, the manager will tend to coose a procedur that shifts the reporting of current period earnings to future periods to reduce these political costs. In contrast to small companies, which avoid political costs because of the need for funds to develop their businesses. 
The results of this study are also not in line with the research conducted by Purwasih (2020), Solichah \& Fachrurrozie (2019), and Kusamadewi (2018), which suggests that the size of the company positively affects accounting conservatism.

\section{CONCLUSIONS AND SUGGESTION}

This study intends to analyze the impact of the proportion of independent commissioners, leverage, and Size of companies on accounting conservatism on State-Owned Enterprises (BUMN) for the period 2017-2019. Based on the results, it can be concluded that leverage has a positive Impact on Accounting Conservatism. Meanwhile, the variable Proportion of Independent Board of Commissioners and Company Size does not affect Accounting Conservatism. Simultaneously, the Proportion of Independent Board of Commissioners, Leverage, and Size has a simultaneous influence on Accounting Conservatism with a coefesien determinant value of $31.85 \%$ and another $68.15 \%$ influenced by other variables. The research implication that researchers can give is as follows:researchers can then add research variables that influence accounting conservatism in state-owned enterprises. Researchers can then add different research periods with researchers to get better results. Based on the research that has been done by the researcher, the limitation in this study is the value of th coefficient of determination (adjusted $\mathrm{R}^{2}$ ) of $31.85 \%$ which indicates that there are other variables that need to be tested in influencing accounting conservatism, which is $68.15 \%$.

\section{REFERENCES}

Andreas, H. H., Ardeni, A., \& Nugroho, P. I. (2017). Konservatisme Akuntansi di Indonesia. Jurnal Ekonomi Dan Bisnis. https://doi.org/10.24914/jeb.v20i1.457

Aristiyani, D. G. U., \& Wirawati, I. G. P. (2013). Pengaruh Debt To Total Assets, Dividen Payout Ratio Dan Ukuran Perusahaan Pada Konservatisme Akuntansi Perusahaan Manufaktur Di Bei. E-Jurnal Akuntansi, 3(3), 216-230.

Dewi, N. K. S. L., \& Suryanawa, I. K. (2014). Pengaruh Struktur Kepemilikan Manajerial, Leverage, dan Financial Distress terhadap Konservatisme Akuntansi. E-Jurnal Akuntansi, $7(1), 223$.

El-Haq, Z. N. S., Zulpahmi, \& Sumardi. (2019). Pengaruh Kepemilikan Manajerial, Kepemilikan Institusional, Growth Opportunities, Dan Profitabilitas Terhadap Konservatisme Akuntansi. Jurnal ASET (Akuntansi Riset), 11(2), 315-328. https://doi.org/10.17509/jaset.v11i2.19940

Febriani, E., Maslichah, \& Junaidi. (2020). Pengaruh Mekanisme Good Corporate Governance, Audit Brand Name Dan Ukuran Perusahaan Terhadap Konservatisme Akuntansi Pada Perusahaan Manufaktur Yang Terdaftar Di Bursa Efek Indonesia Tahun 2016-2018. EJra, 12(09), 15-19.

Hayn, C. K., \& Givoly, D. (2000). The Changing time-series properties of earning, cash flows and accrual: Has financial reporting become more conservative? Journal of Accounting and Economics, 29, 287-320.

Indonesia, R. (2003). Undang-Undang Republik Indonesia Nomor 19 Tahun 2003 Tentang Badan Usaha Milik Negara. Sekretariat Negara.

Jao, R., \& Ho, D. (2019). Pengaruh Struktur Kepemilikan dan Debt Covenant Terhadap Konservatisme Akuntansi. Jurnal Riset Akuntansi Jambi, 2(2), 1-13. https://doi.org/10.35141/jraj.v2i2.426

Kusamadewi, D. A. A. (2018). Pengaruh Kesulitan Keuangan, Ukuran Perusahaan, dan Piutang pada Konservatisme Akuntansi. Jurnal Parameter, 3(1).

Pratanda, R. S., \& Kusmuriyanto. (2014). Pengaruh Mekanisme Good Corporate Governance, 
ANALYSIS THE IMPACT OF THE PROPORTION OF INDEPENDENT COMMISSIONERS, LEVERAGE, AND SIZE ON THE ACCOUNTING CONSERVATISM OF STATE-OWNED ENTERPRISES (BUMN)

Sri Wahjuni Latifah and Saskiya Sasa Difananda

Likuiditas, Profitabilitas, Dan Leverage Terhadap Konservatisme Akuntansi. Accounting Analysis Journal, 3(2), 255-263. https://doi.org/10.15294/aaj.v3i2.4256

Purwasih, D. (2020). Pengaruh Mekanisme Corporate Governance, Ukuran Perusahaan dan Debt to EEquity Ratio terhadap Konservatisme Akuntansi. Jurnal Akuntansi Berkelanjutan Indonesia, 3(3), 309-326.

Rajagukguk, F. D. G., \& Rohman, A. (2020). Pengaruh Mekanisme Corporate Governance Terhadap Konservatisme Akuntansi. Diponegoro Journal of Accounting, 9(4), 1-9. https://doi.org/10.31258/jc.1.1.52-67

Saputra, R. E. (2016). Pengaruh Struktur Kepemilikan Manajerial, Kontrak Utang, Tingkat Kesulitan Keuangan Perusahaan, Peluang Pertumbuhan, Risiko Litigasi Dan Leverage Terhadap Konservatisme Akuntansi. JOMFekon, 3(1), 2207-2221.

Savitri, E. (2016). Konservatisme Akuntansi (Musfialdi (ed.); Cetakan 1). Pustaka Sahila Yogyakarta.

Sekaran, U., \& Bougie, R. (2017). Metode Penelitian untuk Bisnis (Pendekatan Pengembangan-Keahlian) (6th ed.). Salemba Empat.

Solichah, N., \& Fachrurrozie, F. (2019). Effect of Managerial Ownership , Leverage , Firm Size and Profitability on Accounting Conservatism. Accounting Analysis Journal, 8(3), 151157. https://doi.org/10.15294/aaj.v8i3.27847

Sonia Fitriani. (2013). Pengaruh Mekanisme Good Corporate Governance Terhadap Konservatisme Akuntansi (Studi pada Perusahaan Manufaktur Sektor Industri Barang Konsumsi yang Terdaftar di Bursa Efek Indonesia Periode 2009-2012). Journal of Chemical Information and Modeling, 53(9), 1689-1699.

Sugiarto, N., \& Nurhayati, I. (2017). Faktor-Faktor Yang Mempengaruhi Konservatisme Akuntansi Pada Perusahaan Manufaktur Yang Terdaftar Di Bursa Efek Indonesia Tahun 2014-2016. Jurnal Dinamika Akuntansi, Keuangan Dan Perbankan, 6(2), 102-116.

Susanto, B., \& Ramadhani, T. (2016). Faktor-Faktor yang Memengaruhi Konservatisme (Studi pada Perusahaan Manufaktur yang Terdaftar di BEI 2010-2014). Jurnal Bisnis Dan Ekonomi, 23(2), 142-151.

Tista, K. W. N., \& Suryanawa, I. K. (2017). Pengaruh Ukuran Perusahaan Dan Potensi Kesulitan Keuangan Pada Konservatisme Akuntansi Dengan Leverage Sebagai Pemoderasi. E-Jurnal Akuntansi, 18, 2477-2504.

Varadina, A. P. D., \& Diatmika, N. G. A. (2018). Hubungan Ceo Gender dan Leverage Dengan Konservatisme Akuntansi Pada Perusahaan Manufaktur Yang Terdaftar Di Bursa Efek Indonesia Periode 2015-2017. Jurnal Ilmiah Akuntansi Dan Bisnis, 3(1), 36-45.

Wulandini, D., \& Zulaikha. (2012). Pengaruh Karakteristik Dewan Komisaris dan Komite Audit Terhadap Tingkat Konservatisme Akuntansi (Studi Empiris pada Perusahaan Manufaktur yang Terdaftar di BEI Tahun 2008-2010). Diponegoro Journal of Accounting, 1(1), 175-188.

Yuliarti, D., \& Yanto, H. (2017). The Effect of Leverage, Firm Size, Managerial Ownership, Size of Board Commissioners and Profitability to Accounting Conservatism. Accounting Analysis Journal, 6(2), 173-184. https://doi.org/10.15294/aaj.v6i2.16675 